\title{
CONSIDERATIONS AGAINST THE ADMISSION OF
} IOWA.

Gideon Smith Bailey emigrated from Indiana to what is now Iowa in 1837 . He was a factor from his advent in the new country's affairs, and remained an element in the consideration of substantial men from whom he separated in his native State. Territorial Delegate A. C. Dodge recommended him to President Polk in 1845 for the Receivership of Public Moneys at Fairfield, but the recommendation was ignored and General Ver Plank Van Antwerp was appointed. It was on this occasion that Doctor Bailey was assured that he. should be recommended for his choice of positions as United States Marshal or Governor of the Territory. Upon mature consideration Doctor Bailey chose the Marshalship, to which place he was appointed and in which he remained for several years. The Governorship was given to James Clarke, husband of Dodge's sister.

Doctor Bailey preserved for us a vast amount of original material relating to the events in which he figured, embracing his incumbency of the marshal's office, service in Territorial and State Legislatures, and a candidacy for Congress. There occur many valuable communications and lights on numerous important events. Nothing he preserved is of more interest perhaps than communications from Indiana associates interested in the Iowa situation in the days of agitation for admission. Arguments on the subject from political viewpoints, both local and national, have been amply treated. Practical business reasons of the people against the admission are nearly lost sight of, but one of the communications to Doctor Bailey given verbatim herewith discloses some of these.

E: R. H.

Mr. G. S. Bailey Esq.

Bedford Ia. December 1st 1839

\section{Dear Sir,}

I recd. your favour of the 8th Augt. last, but it came while I was absent in the north of Indiana; I spent about 2 months there this fall trying to sell my lands there, preparitory to my removal to Iowa; but did not succeed except in part, and consequently cannot move till spring, when I hope to be able to go; business has called me from home a considerable part of the time since my return from the north, 
and consequently I have neglected to write to you sooner, which negligence I hope you will excuse. I was much gratified at your success in the election in Aingt. last, and much more so to see that you ran the highest poll.

I have recd. the Burlington paper in which the Governor's message \& the organization of the Iowa Teritorial Legislature is given, and I regret to see in said messige a recommendation to memorialize Congress to pass a law authorizing Iowa to form a constitution and State government so soon.

I have no doubt but that you recollect how long it took Indiana to. liquidate the debt she created by going into a State government too soon. While Towa remains a Teritory the Genl. Government pays all the Teritorial expenses, which I consider a matter of much importance to the people at present, as they have no land taxable yet nor will have soon, and as so small a part of the lands of the Teritory have been sold by the Genl. Government it will be many years before there will be any subject of taxation except personal property; consequently you will have nothing but personal property to tax, \& but little of that if you tax it very high, (as you will be obliged to do if you make a state of the Tery. before the lands are taxable,) because the citizens will be likely to do with as little as possible if it is so taxed, and consequently retard the increase of wealth in the state, as well as in some degree check the imigration to it. And furthermore while it remains a Teritory Congress will -make appropriations for improvement of the roads and rivers; which they will cease to do the moment it becomes a State; and consequently all improvement will cease as the State will not be able \& the U. S. will not be willing. I hope therefore that, Gov. Lucas's recommendation will not be complied with, as I can see no good reason why it should, as it will only gratify a few aspirants to office, and as I believe greatly retard the groth and prosperity of one of the fairest portions of this great country. I feel anxious to know how the question of the relocation of the seat of justice of Lee county is likely to be desided; you know why.

Please use your influence to prevent private interest from improperly controling the public good; by having inteligent, honest and disinterested Commissioners to perform that duty.

Please write to me as soon as it may be convenient and as often as you may find leisure.

$$
\text { And believe me to be yours sincerely, }
$$

P. S. If a law should be passed to relocate the seat of "justice of Lee county, please let me know as soon as possible who the Coms. are, when \& where they are to meet and what are the genl. requisitions of the law.

J. B.

- We are requested to state by Capt. J. C. Ainsworth, of the fast running steamer, Kentucky, that a celebration will come off. at Davenport, on the 4 th of July. The Kentucky will leave Montrose on the morning of the $3 \mathrm{~d}$, and arrive in Davenport in time for passengers to engage in the celebration of the day.-Keokuk Register; June 22, 1848. 
Copyright of Annals of Iowa is the property of State of Iowa, by \& through the State Historical Society of Iowa and its content may not be copied or emailed to multiple sites or posted to a listserv without the copyright holder's express written permission. However, users may print, download, or email articles for individual use. 